\title{
Correction to: Novel Biallelic NSUN3 Variants Cause Early-Onset Mitochondrial Encephalomyopathy and Seizures
}

\author{
Arumugam Paramasivam ${ }^{1,2} \cdot$ Angamuthu K. Meena $^{3} \cdot$ Challa Venkatapathi $^{1} \cdot$ Robert D. S. Pitceathly $^{4}$ (ID $\cdot$ \\ Kumarasamy Thangaraj ${ }^{1}$ (i)
}

Published online: 16 July 2020

(C) The Author(s) 2020

\section{Correction to: Journal of Molecular Neuroscience https://doi.org/10.1007/s12031-020-01595-8}

The article "Novel Biallelic NSUN3 Variants Cause EarlyOnset Mitochondrial Encephalomyopathy and Seizures", written by Arumugam Paramasivam, Angamuthu K. Meena, Challa Venkatapathi, Robert D.S. Pitceathly and Kumarasamy Thangaraj, was originally published electronically on the publisher's internet portal on 02 June 2020 without open access.

With the author(s)' decision to opt for Open Choice the copyright of the article changed on July 2020 to $($ ) The Author(s) 2020 and the article is forthwith distributed under a Creative Commons Attribution 4.0 International License (https:// creativecommons.org/licenses/by/4.0/), which permits use, sharing, adaptation, distribution and reproduction in any medium or format, as long as you give appropriate credit to the original author(s) and the source, provide a link to the Creative Commons license, and indicate if changes were made.

The original article has been corrected.

Open Access This article is licensed under a Creative Commons Attribution 4.0 International License, which permits use, sharing, adaptation, distribution and reproduction in any medium or format, as long as you give appropriate credit to the original author(s) and the source, provide a link to the Creative Commons licence, and indicate if changes were made. The images or other third party material in this article are included in the article's Creative Commons licence, unless indicated otherwise in a credit line to the material. If material is not included in the article's Creative Commons licence and your intended use is not permitted by statutory regulation or exceeds the permitted use, you will need to obtain permission directly from the copyright holder. To view a copy of this licence, visit http://creativecommons.org/licenses/by/4.0/.

Publisher's Note Springer Nature remains neutral with regard to jurisdictional claims in published maps and institutional affiliations.

The online version of the original article can be found at https://oi.org/ 10.1007/s12031-020-01595-8

Kumarasamy Thangaraj

thangs@ccmb.res.in

1 CSIR-Centre for Cellular and Molecular Biology, Hyderabad, India

2 BRULAC-DRC, Saveetha Dental College and Hospital, Saveetha Institute of Medical and Technical Sciences, Saveetha University, Chennai, India

3 Department of Neurology, Nizam's Institute of Medical Sciences, Hyderabad, India

4 Department of Neuromuscular Diseases, UCL Queen Square Institute of Neurology and The National Hospital for Neurology and Neurosurgery, London, UK 